\title{
FAKTOR-FAKTOR RASIO KEUANGAN DALAM MEMPREDIKSI PERTUMBUHAN LABA (STUDI KASUS PERUSAHAAN RITEL DI BEI 2016-2018)
}

\author{
Muzayyanah ${ }^{1}$ \\ Harun Purwantoro ${ }^{2}$ \\ ${ }^{1}$ Fakultas Ekonomi, Universitas Muhammadiyah Cirebon \\ Email: muzayyanah@umc.ac.id \\ ${ }^{2}$ Fakultas Ekonomi, Universitas Muhammadiyah Cirebon \\ Email: harunpurwanto72@gmail.com
}

\begin{abstract}
Financial ratios are used to evaluate the company's financial condition and performance. The purpose of this study was to determine profit growth in retail companies affected by Current Ratio (CR), Debt Equity Ratio (DER), Total Asset Turn Over (TATO), Net Profit Margin (NPM). The subjects in this study were 10 retail companies listed on the Indonesia Stock Exchange in 2016-2018. Data analysis uses multiple linear regressions. The results of data analysis showed partial test of variable Current Ratio (CR) Debt Equity Ratio (DER), Total Asset Turn Over (TATO), Net Profit Margin (NPM) has no effect on Profit Growth. Meanwhile, simultaneously all independent variables have no significant effect on profit growth in retail companies in 2016-2018.
\end{abstract}

Keywords : Current Ratio (CR), Debt Equity Ratio (DER), Total Asset Turn Over (TATO), Net Profit Margin (NPM), Profit Growt

\section{PENDAHULUAN}

Ukuran Laba menggambarkan kinerja manajemen dalam menghasilkan profit untuk membayar bunga kreditur, deviden investor, dan pajak pemerintah. Laba merupakan dasar perhitungan pajak, pedoman dalam menentukan kebijakan investasi dan pengambilan keputusan, dasar dalam peramalan maupun kejadian ekonomi perusahaannya lain dimasa yang akan datang, dasar dalam perhitungan dan penilaian efisiensi dalam menjalankan perusahaan serta sebagai dasar dalam penilaian prestasi atau kinerja perusahaan (Hery, 2017).

Laba diharapkan mengalami kenaikan setiap periode, untuk mengestimasikan laba di periode akan datang yang dapat dilakukan dengan menganalisis laporan keuangan. Analasis laporan keuangan yang digunakan ialah analisis rasio. Analisis rasio adalah berorientasi dengan masa depan, artinya bahwa dengan analisis rasio dapat digunakan sebagai alat untuk meramalkan keadaan keuangan serta hasil usaha di masa yang akan datang. Menurut Fraser dan Ormiston (2008) terdapat empat rasio keuangan utama yaitu rasio likuiditas, rasio leverage, rasio aktivitas, dan rasio profitabilitas.

Dikutip dari berita Bisnis.com tahun 2019, penjualan ritel modern ditaksir menembus Rp. 256 Triliun pada 2019, atau tumbuh sekitar 10\% dari realisasi tahun lalu. Proyeksi tersebut terbilang moderat tetapi masih lebih baik jika dibandingkan capaian pertumbuhan bisnis ritel modern pada 2017 yang hanya $3.7 \%$. Disamping itu rencana pemecahan masalah dengan pergeseran pola belanja masyarakat, terlebih selektivitas masyarakat dalam menggunakan uang sudah meningkat. Daya beli masyarakat masih besar, upah minimum yang terus meningkat membuat potensi daya beli naik serta inflasi yang lebih kecil sehingga industri ritel masih punya peluang besar. 
Tabel 1

Pertumbuhan Laba (LABA)

Perusahaan Ritel Di Bursa Efek Indonesia Periode 2016-2018

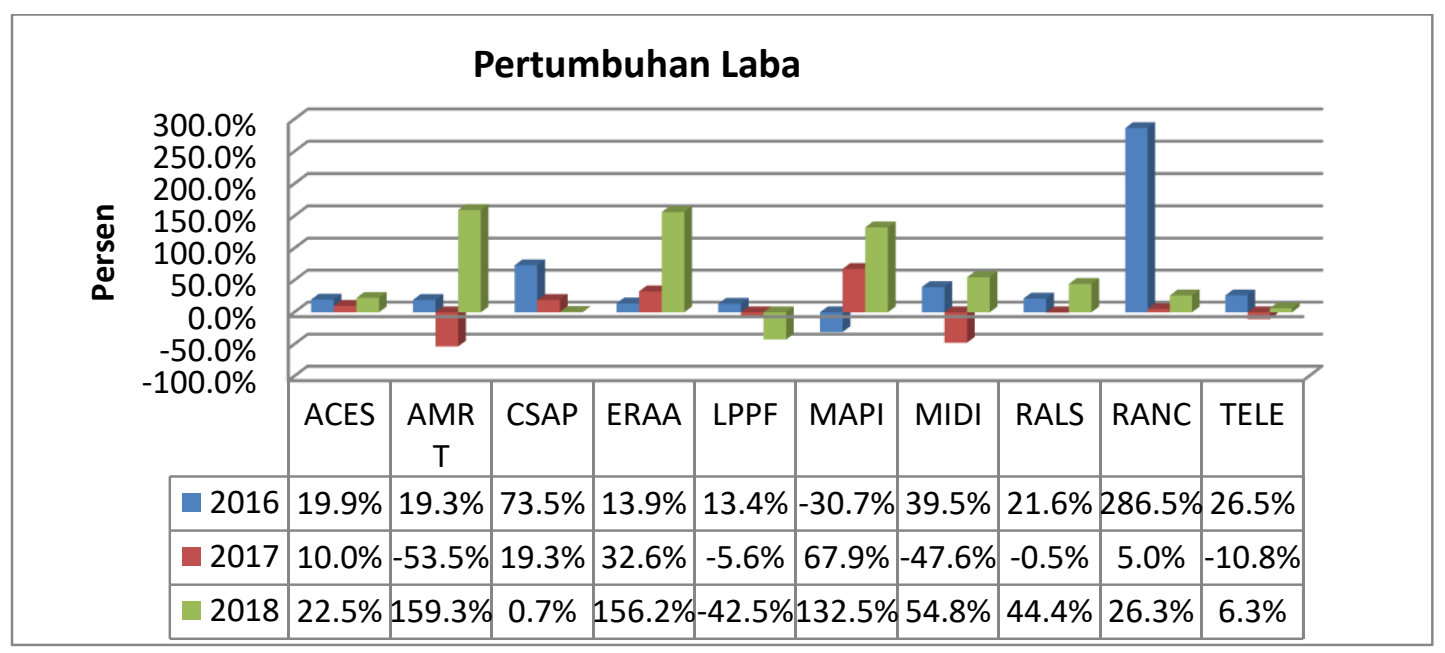

Sumber : Dari data diolah

Rasio keuangan (Hery,2017) Rasio Likuiditas adalah rasio yang menunjukan kemampuan perusahaan dalam memenuhi kewajiban atau membayar utang jangka pendek. Rasio Likuiditas tersebut dapat diukur dengan salah satu cara yaitu Current Ratio (CR). Current Ratio mengukur kemampuan suatu perusahaan untuk membayar hutang lancar dengan menggunakan aktiva lancar yang dimiliki. Rasio Leverage merupakan rasio yang digunakan untuk mengukur sejauh mana aset perusahaan dibiayai dengan utang baik kewajiban jangka pendek maupun jangka panjang. Salah satu Rasio Leverage yakni Debt to Equity Ratio (DER) merupakan rasio hutang yang digunakan untuk mengukur perbandingan antara total hutang dengan total aktiva. Rasio ini menunjukkan seberapa besar aktiva perusahaan dibiayai oleh hutang atau seberapa besar hutang perusahaan berpengaruh terhadap pengelolaan aktiva.

Rasio Aktivitas, merupakan rasio yang digunakan untuk mengukur efektivitas perusahaan dalam menggunakan aktiva yang dimilikinya atau tingkat efisiensi pemanfaatan sumber daya perusahaan ( penjualan, persediaan, penagihan piutang, dan lainnya). Salah satu Rasio Aktivitas adalah Total Asset Turnover (TAT) rasio yang digunakan untuk mengukur keefektifan total aset yang dimiliki perusahaan dalam menghasilkan penjualan, dengan kata lain untuk mengukur berapa jumlah penjualan yang akan dihasilkan. Rasio Profitabilitas, merupakan rasio yang mengukur kemampuan perusahaan untuk menghasilkan laba dengan menggunakan sumber-sumber yang dimiliki perusahaan, seperti aktiva, modal, atau penjualan perusahaan. Salah satu Rasio Profitabilitas adalah net profit margin (NPM). Net profit margin dapat dihitung dengan membandingkan antara laba bersih setelah pajak terhadap penjualan bersih.

Menurut penelitian Mei Hotma Mariati Munte and Thioly Theresia Sitanggang (2015) menunjukkan bahwa Current Rasio berpengaruh signifikan terhadap pertumbuhan laba satu tahun mendatang. Akan tetapi penelitian yang dilakukan Ageng Setiaji (2017) rasio likuiditas yang tidak berpengaruh positif terhadap pertumbuhan laba satu tahun mendatang adalah Current Ratio. Sedangkan penelitian Yuni Ajisti Herti, Safitri dan Yuna (2019) dan I Nyoman Kusuma Adnyana Mahaputra (2012) menunjukkan bahwa DER berpengaruh postif yang tidak signifikan terhadap pertumbuhan laba. Sedangkan penelitian Suharti, Dhea serta Yayuk Retnowati, Jeni Susyanti dan Budi Wahono menunjukkan bahwa DER tidak berpengaruh signifikan terhadap pertumbuhan laba.

Penelitian I Nyoman Kusuma Andyana Mahaputra (2012), Maria Majesty Sihura dan Romasi Lumban Gaol (2016) serta Victorson Taruh menunjukkan bahwa TAT berpengaruh positif terhadap pertumbuhan laba. Sedangkan penelitian yang dilakukan Ageng, Safitri dan Yuna (2019), Dhany Lia Gustina, Andhi Wijayanto (2015) Suharti, Dhea serta Yayuk Retnowati, Jeni Susyanti dan Budi Wahono menunjukkan bahwa TAT tidak berpengaruh signifikan terhadap pertumbuhan laba dan menurut I Nyoman Kusuma Adnyana Mahaputra (2012) Mei Hotma Mariati Munte and Thioly Theresia 
Sitanggang (2015), Yayuk Retnowati, Jeni Susyanti dan Budi Wahono serta Boy Fadli (2015) dalam penelitiannya menunjukkan bahwa NPM berpengaruh positif terhadap pertumbuhan laba satu tahun ke depan. Akan tetapi hasil penelitian Safitri dan Yuna (2019) dan Suharti, Dhea menunjukkan bahwa NPM tidak berpengaruh signifikan terhadap pertumbuhan laba satu tahun ke depan.

Berdasarkan uraian diatas bahwa analisis rasio keuangan bertujuan untuk mendapat gambaran tentang baik buruknya keadaan keuangan suatu perusahaan. Dan adanya perbedaan antar penelitianpenelitian terdahulu (research gap) dan fenomena yang ada, maka penelitian ini perlu dilakukan untuk menelaah kembali pengaruh rasio-rasio keuangan (CR, DER, TAT, dan NPM) terhadap pertumbuhan laba pada perusahaan ritel yang terdaftar di Bursa Efek Indonesia (BEI) pada periode 2016 sampai dengan 2018 karena sangat penting untuk memberi suatu pemahaman tentang rasio keuangan yang ada di perusahaan begitupun bagi perusahaan dapat memperoleh suatu informasi tentang kekuatan dan kelemahan perusahaan, maka peneliti tertarik akan meneliti tentang "Faktor - Faktor Rasio Keuangan dalam memprediksi pertumbuhan laba".

\section{KAJIAN PUSTAKA DAN PEGEMBANGAN HIPOTESIS Kajian Pustaka}

\section{Teori Sinyal (Signaling Theory)}

Teori sinyal didasarkan pada asumsi bahwa informasi yang diterima oleh masing-masing pihak tidak sama. Dengan kata lain, teori sinyal berkaitan dengan asimetri informasi. Teori sinyal menunjukkan adanya asimetri informasi antara manajemen perusahaan dengan pihak-pihak yang berkepentingan dengan informasi. Manajer memberikan informasi melalui laporan keuangan bahwa mereka menerapkan kebijakan akuntansi konservatisme yang menghasilkan laba yang lebih berkualitas karena prinsip ini mencegah perusahaan melakukan tindakan membesar-besarkan laba dan membantu pengguna laporan keuangan dengan menyajikan laba dan aktiva yang tidak overstate.

Brigham dan Houston (2001) menyatakan bahwa isyarat adalah suatu tindakan yang diambil manajemen perusahaan yang memberi petunjuk bagi investor tentang bagaimana manajemen memandang prospek perusahaan. Perusahaan dengan prospek yang menguntungkan akan mencoba menghindari penjualan saham dan mengusahakan setiap modal yang baru diperlukan dengan cara-cara lain. Sedangkan dengan prospek yang kurang menguntungkan akan cenderung untuk menjual saham.

\section{Teori Keagenan (Agency Theory)}

Teori pecking order menyatakan bahwa jumlah hutang yang diterbitkan perusahaan akan bergantung pada kebutuhannya akan pendanaan eksternal. Teori ini menyarankan bahwa manajer keuangan harus berusaha mempertahankan setidaknya beberapa kelonggaran keuangan yaitu, cadangan kas yang siap atau kapasitas pinjaman yang belum digunakan. Sehingga pada intinya, perusahaan akan lebih pmenyukai pendanaan internal dalam bentuk laba ditahan daripada pendanaan eksternal dalam bentuk hutang.

Pecking order (Husnan,2004) menjelaskan bahwa perusahaan yang profitable meminjam dengan jumlah yang sedikit, sedangkan perusahaan kurang profitable akan cenderung hutang yang lebih besar karena dana internal yang tidak cukup atau hutang menjadi sumber eksternal yang paling disukai.

\section{Laporan Keuangan}

Menurut Kasmir (2013:7) secara sederhana dimana pengertian laporan keuangan adalah laporan yang menunjukkan kondisi keuangan perusahaan saat ini atau periode kedepannya. Maksud dan tujuan laporan keuangan menunjukkan kondisi keuangan perusahaan. Menurut PSAK No. 1 (2015: 1), "Laporan keuangan adalah penyajian terstruktur dari posisi keuangan dan kinerja keuangan suatu entitas" Laporan keuangan merupakan bagian dari proses pelaporan keuangan.

Laporan keuangan yang lengkap biasanya meliputi neraca, laporan labarugi, laporan perubahan posisi keuangan (yang dapat disajikan dalam berbagai cara misalnya, sebagai laporan arus kas, atau laporan arus dana),catatan dan laporan lain serta materi penjelasan yang merupakan bagianintegral dari laporan keuangan. Disamping itu juga termasuk skedul daninformasi tambahan yang berkaitan dengan laporan tersebut, misalnya,informasi keuangan segmen industri dan geografis serta pengungkapan pengaruh perubahan harga. 


\section{Rasio Keuangan}

Rasio keuangan adalah membandingkan angka-angka yang ada dalam laporan keuangan untuk mengetahui posisi keuangan suatu perusahaan serta menilai kinerja manajemen dalam suatu periode tertentu (kasmir, 2008 : 14). Kasmir (2009) menjelaskan terdapat beberapa jenis rasio keuangan, yaitu:

1. Rasio Likuiditas

Menurut Hery (2017) Rasio Likuiditas adalah rasio yang menunjukan kemampuan perusahaan dalam memenuhi kewajiban atau membayar utang jangka pendek.

Rasio Likuiditas tersebut dapat diukur dengan salah satu cara yaitu Current Ratio (CR). Current Ratio mengukur kemampuan suatu perusahaan untuk membayar hutang lancar dengan menggunakan aktiva lancar yang dimiliki.

Rasio lancar/Current Ratio dapat dirumuskan sebagai berikut:

$$
\text { Current Ratio }=\frac{\text { aktiva lancar }}{\text { kewajiban lancar }}
$$

\section{Rasio Solvabilitas}

Menurut Kasmir (2014:150) Rasio solvabilitas adalah rasio yang menggambarkan kemampuan perusahaan dalam membayar kewjiban jangka panjangnya/ kewajiban-kewajibannya apabila perusahaan di likuidasi. Rasio solvabilitas dapat diukur dengan salah satu cara yaitu Debt Equity Ratio. Rasio hutang modal menggambarkan sampai sejauh mana modal pemilik dapat menutupi hutang-hutang kepada pihak luar dan merupakan rasio yang mengukur hingga sejauh mana perusahaan dibiayai dari hutang. Rasio Debt Equity Raio dapat dirumuskan sebagai berikut

$$
\text { Debt Equity Ratio }=\frac{\text { total hutang }}{\text { modal }}
$$

\section{Rasio Aktivitas}

Menurut Fahmi (2013:132), rasio aktivitas adalah rasio yang menggambarkan sejauh mana suatu perusahaan mempergunakan sumber daya yang dimilikinya guna menunjang aktivitas perusahaan, dimana penggunaan aktivitas ini dilakukan secara sangat maksimal dengan maksud memperoleh hasil yang maksimal. Rasio Aktivitas dapat diukur dengan salah satu cara yaitu, Total Asset Turnover. Perputaran total aktiva merupakan rasio yang digunakan untuk mengukur berapa jumlah penjualan yang diperoleh dari tiap rupiah aktiva. Menurut Kasmir (2014), rumus rasio aktivitas untuk mencari perputaran total aktiva, yaitu:

$$
\text { Total Asset Turnover : } \frac{\text { Penjualan }}{\text { Total aktiva }}
$$

\section{Rasio Profitabilitas}

Rasio profitabilitas adalah rasio yang digunakan untuk mengukur kemampuan suatu perusahaan dalam mendapatkan laba. Ditekankan pada rasio ini karena hal ini berkaitan erat dengan kelangsungan hidup perusahaan.

Rasio Profitabilitas dapat diukur dengan salah satu cara yaitu Net Profit Margin. Net profit margin digunakan untuk mengukur rupiah laba bersih yang dihasilkan oleh setiap satu rupiah penjualan dan mengukur seluruh efisien, baik produksi, administrasi, pemasaran, pendanaan, penentuan harga maupun manajemen pajak. Semakin tinggi rasionya menunjukkan kemampuan perusahaan menghasilkan laba yang tinggi pada tingkat penjualan tertentu, tetapi jika rasionya rendah menunjukkan penjualan yang terlalu rendah untuk tingkat biaya tertentu, atau biaya yang terlalu tinggi untuk tingkat penjualan tertentu, atau kombinasi dari kedua hal tersebut (Prastowo dan Juliaty, 2003:91). Rumus rasio profitabilitas untuk mencari Net profit margin, yaitu:

$$
\text { Net Profit Margin : } \frac{\text { laba bersih setelah pajak }}{\text { penjualan bersih }}
$$




\section{Laba}

Menurut FASB Statement of Financial Accounting Concepts No 1 dalam Hendrikson (1996) menyatakan bahwa sasaran utama pelaporan keuangan adalah informasi tentang prestasi perusahaan yang disajikan melalui pengukuran laba dan kompenennya. FASB Statement of Financial Accounting Concepts No 1 menganggap bahwa laba akuntansi merupakan pengukuran yang baik atas prestasi perusahaan dan bahwa laba akuntansi dapat digunakan dalam prediksi arus kas yang akan datang.

Karakteristik laba akuntansi menurut Belkaoui dalam Chariri dan Ghozali (2007) terdiri dari lima yaitu:

1. Laba akuntansi didasarkan pada transaksi aktual terutama yang berasal dari penjualan barang/ jasa

2. Laba akuntansi didasarkan pada postulat periodesasi dan mengacu pada kinerja perusahaan selama satu periode tertentu

3. Laba akuntansi didasarkan pada prinsip pendapatan yang memerlukan pemahaman khusus tentang definisi, pengukuran, dan pengakuan pendapatan

4. Laba akuntansi memerlukan pengukuran tentang biaya (expenses) dalam bentuk cost historis

5. Laba akuntansi menghendaki adanya penandingan (matching) antara pendapatan dengan biaya yang relevan dan berkaitan dengan pendapatan tersebut.

Pertumbuhan laba merupakan salah satu rasio pertumbuhan yang dapat digunakan untuk mengukur kinerja perusahaan. Pertumbuhan laba (Harahap, 2011) adalah rasio yang menunjukkan kemampuan perusahaan meningkatkan laba bersih dibanding tahun sebelumnya. Laba bersih (Kasmir, 2008) merupakan laba yang telah dikurangi biaya biaya (beban perusahaan pada suatu periode tertentu) termasuk pajak. Pertumbuhan laba merupakan selisih laba bersih tahun tertentu dengan laba bersih tahun sebelumnya dibagi dengan laba bersih tahun sebelumnya. Pertumbuhan laba dirumuskan sebagai berikut (Harahap, 2011) :

$$
\begin{array}{ll}
\text { Pertumbuhan Laba }(\mathrm{Y}): \frac{Y t-Y t 1}{Y t 1} \\
\mathrm{Y} & : \text { Pertumbuhan Laba } \\
\mathrm{Yt} & : \text { Laba setelah pajak periode tertentu } \\
\mathrm{Yt}^{1} & : \text { Laba setelah pajak pada periode sebelumnya }
\end{array}
$$

\section{Hipotesis}

1. Pengaruh Rasio Lancar (current ratio) terhadap pertumbuhan laba

Current Ratio mengukur kemampuan suatu perusahaan untuk membayar hutang lancar dengan menggunakan aktiva lancar yang dimiliki. Semakin baik perusahaan dalam mengelola aktiva lancar dan kewajiban jangka pendek, maka operasional perusahaan semakin baik. Penelitian Mei Hotma Mariati Munte and Thioly Theresia Sitanggang (2015), menunjukkan bahwa Current Rasio berpengaruh terhadap pertumbuhan laba satu tahun mendatang. Berdasarkan uraian tersebut maka dapat dirumuskan hipotesis sebagai berikut :

H1 : CR berpengaruh terhadap pertumbuhan laba.

2. Pengaruh rasio hutang modal (debt equity ratio) terhadap pertumbuhan laba

Semakin tinggi rasio DER berarti modal sendiri semakin sedikit dibanding dengan hutangnya. Bagi perusahaan sebaiknya, besarnya hutang tidak boleh melebihi modal sendiri agar beban tetapnya tidak terlalu tinggi. Semakin kecil rasio ini semakin baik. Maksudnya, semakin kecil porsi hutang terhadap modal, semakin aman. Penelitian Yuni Ajisti Herti, Safitri dan Yuna (2019) dan I Nyoman Kusuma Andyana Mahaputra (2012) menunjukkan bahwa DER berpengaruh postif yang tidak signifikan terhadap pertumbuhan laba. Sedangkan penelitian Suharti menunjukkan bahwa DER tidak berpengaruh signifikan terhadap pertumbuhan laba.Berdasarkan uraian tersebut maka dapat dirumuskan hipotesis sebagai berikut :

H2 : DER berpengaruh terhadap pertumbuhan laba 
3. Pengaruh rasio perputaran total aktiva (Total asset Turnover) terhadap pertumbuhan laba

Rasio ini memperlihatkan sejauh mana efektivitas perusahaan menggunakan aktiva tetapnya. Semakin tinggi rasio ini berarti semakin efektif proporsi aktiva tetap tersebut. Penelitian Maria Majesty Sihura dan Romasi Lumban Gaol (2016) serta Victorson Taruh menunjukkan bahwa TAT berpengaruh positif terhadap pertumbuhan laba.Berdasarkan uraian tersebut maka dapat dirumuskan hipotesis sebagai berikut :

H3 : TATO berpengaruh terhadap pertumbuhan laba

4. Pengaruh rasio marjin laba bersih (Net Profit Margin) terhadap pertumbuhan laba Semakin tinggi rasio NPM menunjukkan kemampuan perusahaan menghasilkan laba yang tinggi pada tingkat penjualan tertentu. Penelitian I Nyoman Kusuma Adnyana Mahaputra (2012) Mei Hotma Mariati Munte and Thioly Theresia Sitanggang (2015), Yayuk Retnowati, Jeni Susyanti dan Budi Wahono serta Boy Fadli (2015) dalam penelitiannya menunjukkan bahwa NPM berpengaruh positif terhadap pertumbuhan laba satu tahun ke depan. Akan tetapi hasil penelitian Safitri dan Yuna (2019) dan Suharti, Dhea menunjukkan bahwa NPM tidak berpengaruh signifikan terhadap pertumbuhan laba satu tahun ke depan. Berdasarkan uraian tersebut maka dapat dirumuskan hipotesis sebagai berikut: H4 : NPM berpengaruh terhadap pertumbuhan laba

5. Pengaruh Rasio keuangan secara simultan terhadap pertumbuhan laba

I Nyoman Kusuma Adnyana Mahaputra (2012) dalam penelitiannya menunjukkan bahwa rasio berpengaruh positif terhadap pertumbuhan laba satu tahun ke depan. Berdasarkan uraian tersebut maka dapat dirumuskan hipotesis sebagai berikut :

H5 : Rasio keuangan berpengaruh terhadap pertumbuhan laba

\section{METODE PENELITIAN}

Penelitian ini menggunakan pendekatan kuantitatif untuk menguji hipotesis. Populasi penelitian ini terdiri dari 27 perusahaan ritel yang tedaftar di Bursa Efek Indonesia periode 2016 sampai dengan 2018. Pengambilan sampel dalam penelitian ini menggunakan metode purposive sampling. Purposive sampling adalah teknik penentuan sampel dengan pertimbangan dan kriteria kriteria tertentu (Sujarweni, 2015 : 88). Jadi jumlah sampel dalam penelitian ini sebanyak 10 perusahaan. Metode analisis data ini menggunakan analisis deskriptif kuantitatif dan melakukan uji asumsi klasik serta menggunakan analisis regresi berganda untuk dapat mengetahui ada pengaruh secara parsial dan simultan atau tidak dari variabel bebas terhadap variabel terikat.

\section{HASIL DAN PEMBAHASAN}

\section{Hasil Penelitian}

Uji Parsial (T)

Tabel 2

\begin{tabular}{|c|c|c|c|c|c|c|}
\hline \multirow{2}{*}{\multicolumn{2}{|c|}{ Model }} & \multicolumn{2}{|c|}{ Unstandardized Coefficients } & \multirow{2}{*}{$\begin{array}{c}\begin{array}{c}\text { Standardized } \\
\text { Coefficients }\end{array} \\
\text { Beta }\end{array}$} & \multirow[b]{2}{*}{$\mathrm{t}$} & \multirow[b]{2}{*}{ Sig. } \\
\hline & & B & Std. Error & & & \\
\hline \multirow[t]{5}{*}{1} & (Constant) & 1,476 & 1,339 & & 1,103 & 281 \\
\hline & Curernt Ratio &,- 445 & ,306 &,- 384 & $-1,457$ & , 158 \\
\hline & Debt Equity Ratio &,- 845 &, 450 &,- 549 & $-1,878$ &, 072 \\
\hline & $\begin{array}{l}\text { Total Asset } \\
\text { Turnover }\end{array}$ & ,483 & ,621 & , 172 & ,779 & ,444 \\
\hline & Net Profit Margin &,- 930 & 1,493 &,- 160 &,- 623 &, 539 \\
\hline
\end{tabular}

a. Dependent Variable: Pertumbuhan Laba 

bahwa:

Berdasarkan perhitungan dengan menggunakan Uji t secara parsial pada tabel 4,7 ditemukan

1. Pengaruh CR terhadap pertumbuhan laba secara parsial Current Ratio tidak berpengaruh terhadapPertumbuhan Laba.

2. Pengaruh DER terhadap pertumbuhan laba secara parsial Debt Equity Ratio tidak berpengaruh terhadap Pertumbuhan Laba.

3. Pengaruh TATO terhadap pertumbuhan laba secara parsial Total Asset Turnover tidak berpengaruh terhadap Pertumbuhan Laba.

4. Pengaruh NPM terhadap pertumbuhan laba secara parsial Net Profit Margin tidak berpengaruh terhadap Pertumbuhan Laba.

Uji Simultan (F)

Tabel 3

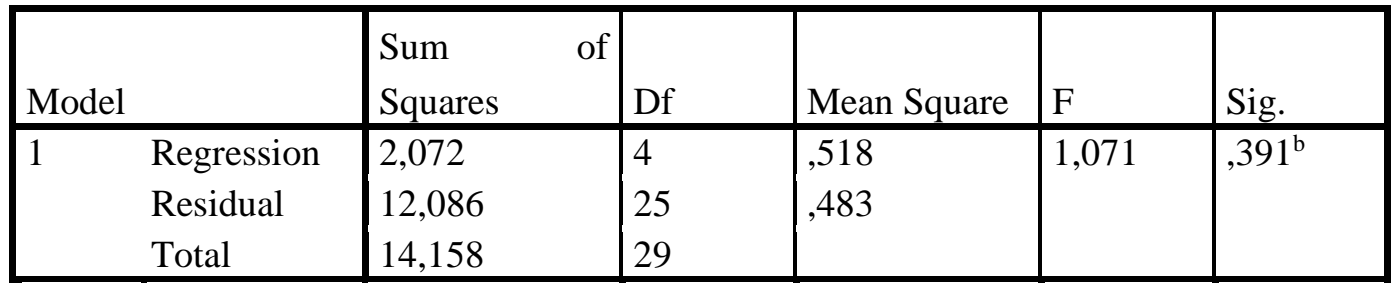

a. Dependent Variable: Pertumbuhan Laba

b. Predictors: (Constant), Net Profit Margin, Curernt Ratio, Total Asset Turnover, Debt Equity Ratio

Berdasarkan Tabel 4.8 diketahui $\mathrm{F}$ hitung adalah 1,071 < nilai $\mathrm{F}$ tabel 2,69 (F tabel tersaji di lampiran) dan Nilai Sig. 0,391 >0,05, maka variabel CR, DER, TATO, NPM secara simultan tidak berpengaruh signifikan terhadap pertumbuhan laba.

\section{PEMBAHASAN}

\section{Pengaruh CR (Current Ratio) terhadap pertumbuhan laba}

Pengaruh CR (Current Ratio) mengukur kemampuan suatu perusahaan untuk membayar hutang lancar dengan menggunakan aktiva lancar yang dimiliki. Semakin baik perusahaan dalam mengelola aktiva lancar dan kewajiban jangka pendek, maka operasional perusahaan semakin baik. Hasil pengujian Pengujian secara parsial menunjukkan berpengaruh signifikan terhadap pertumbuhan laba.

Hasil penelitian ini mendukung penelitian yang dilakukan oleh Suharti (2019) dalam judul "Analisis Pengaruh Current Ratio, Debt to Equity Ratio, Net Profit Margin dan Total Assets Turnover terhadap perubahan Laba Perusahaan Pertambangan Batu Bara yang terdaftar di BEI tahun 2013-2017", dan Ageng setiaji (2017) "Pengaruh Rasio Keuangan terhadap Pertumbuhan Laba pada Perusahaan Infrastruktur, Utilitas, dan Transportasi yang terdaftar di BEI periode 2013 - 2016".

\section{Pengaruh DER (Debt Equity Ratio) terhadap pertumbuhan laba}

Pengaruh DER (Debt Equity Ratio) mengukur seberapa hutang dibiayai modal. dihitung dengan membagi total hutang dengan modal. Semakin tinggi rasio DER berarti modal sendiri semakin sedikit dibanding dengan hutangnya. Bagi perusahaan sebaiknya, besarnya hutang tidak boleh melebihi modal sendiri agar beban tetapnya tidak terlalu tinggi. Semakin kecil rasio ini semakin baik. Maksudnya, semakin kecil porsi hutang terhadap modal, semakin aman. Hasil pengujian Pengujian secara parsial menunjukkan DER bernilai negatif sehingga dapat dinyatakan bahwa DER tidak berpengaruh terhadap pertumbuhan laba.

Hasil penelitian ini mendukung penelitian yang dilakukan oleh Suharti (2019) dalam judul "Analisis Pengaruh Current Ratio, Debt to Equity Ratio, Net Profit Margin dan Total Assets Turnover terhadap Perubahan Laba Perusahaan Pertambangan Batu Bara yang terdaftar di BEI tahun 2013-2017", Ageng setiaji (2017) "Pengaruh Rasio Keuangan terhadap Pertumbuhan Laba pada Perusahaan Infrastruktur, Utilitas, dan Transportasi yang terdaftar di BEI periode 2013 - 2016" dan Yuni adjesti herni (2019) "Pengaruh Rasio Keuangan Terhadap Pertumbuhan Laba Pada Perusahaan Asuransi Yang Terdaftar Di Bursa Efek Indonesia. 


\section{Pengaruh TATO (Total Asset Turnover) terhadap pertumbuhan laba.}

Pengaruh TATO (Total Asset Turnover) Rasio ini mengukur sejauh mana kemampuan perusahaan menghasilkan penjualan berdasarkan aktiva tetap yang dimiliki perusahaan. Rasio ini memperlihatkan sejauh mana efektivitas perusahaan menggunakan aktiva tetapnya. Semakin tinggi rasio ini berarti semakin efektif proporsi aktiva tetap tersebut. Hasil pengujian Pengujian secara parsial menunjukkan TATO bernilai negatif, sehingga dapat dinyatakan bahwa TATO tidak berpengaruh terhadap pertumbuhan laba.

Hasil penelitian ini mendukung penelitian yang dilakukan oleh Suharti (2019) dalam judul "Analisis Pengaruh Current Ratio, Debt to Equity Ratio, Net Profit Margin dan Total Assets Turnover terhadap perubahan laba perusahaan pertambangan Batu bara yang terdaftar di BEI tahun 2013-2017", Yayuk Retnowati (2018) "Pengaruh Quick Ratio, Debt to Equity Ratio, Total Asset Turnover dan Net Profit Margin terhadap pertumbuhan Laba (studi pada perusahaan pertambangan sub sektor batubara yang terdaftar Di bei tahun 2014-2017)" dan Ageng Setiaji (2017) “Pengaruh Rasio Keuangan terhadap Pertumbuhan Laba Pada Perusahaan Infrastruktur, Utilitas, dan Transportasi yang terdaftar di Bursa Efek Indonesia (BEI) Periode 2013 - 2016.

\section{Pengaruh NPM (Net Profit Margin) terhadap pertumbuhan laba}

Pengaruh NPM (Net Profit Margin) mengukur rupiah laba bersih yang dihasilkan oleh setiap satu rupiah penjualan dan mengukur seluruh efisien, baik produksi, administrasi, pemasaran, pendanaan, penentuan harga maupun manajemen pajak. Semakin tinggi rasionya menunjukkan kemampuan perusahaan menghasilkan laba yang tinggi pada tingkat penjualan tertentu. Hasil pengujian Pengujian secara parsial menunjukkan NPM bernilai negatif, sehingga dapat dinyatakan bahwa NPM tidak berpengaruh terhadap pertumbuhan laba.

Hasil penelitian ini mendukung penelitian yang dilakukan oleh Yuni Safitri (2019) dalam judul "Analisis Pengaruh Rasio Keuangan (Likuiditas, Solvabilitas, Aktivitas, dan Profitabilitas) Terhadap Pertumbuhan Laba pada Perusahaan Manufaktur yang Terdaftar di Bursa Efek Indonesia Periode 2011 - 2016" dan Suharti (2019) dalam judul “Analisis Pengaruh Current Ratio, Debt to Equity Ratio, Net Profit Margin dan Total Assets Turnover terhadap perubahan laba perusahaan pertambangan Batu bara yang terdaftar di BEI tahun 2013-2017”.

\section{Pengaruh CR,DER,TATO Dan NPM terhadap pertumbuhan laba}

Hasil pengujian Pengujian secara bersama-sama menunjukkan CR,DER,TATO dan NPM secara bersama-sama tidak berpengaruh terhadap pertumbuhan laba.

\section{KESIMPULAN}

Berdasarkan hasil pengujian hipotesis dan mengacu pada perumusan serta tujuan dari penelitian ini, maka dapat ditarik kesimpulan-kesimpulan sebagai berikut :

1. Berdasarkan hasil uji parsial dengan uji t, bahwa Current Rasio tidak berpengaruh terhadap pertumbuhan laba pada perusahaan ritel yang terdapat di Bursa Efek Indonesia.

2. Berdasarkan hasil uji parsial dengan uji t, bahwa Debt Equity Ratio tidak berpengaruh terhadap pertumbuhan laba pada perusahaan ritel yang terdapat di Bursa Efek Indonesia.

3. Berdasarkan hasil uji parsial dengan uji t, bahwa Total Asset Turnover tidak berpengaruh terhadap pertumbuhan laba pada perusahaan ritel yang terdapat di Bursa Efek Indonesia.

4. Berdasarkan hasil uji parsial dengan uji t, bahwa Net Profit Margin tidak berpengaruh terhadap pertumbuhan laba pada perusahaan ritel yang terdapat di Bursa Efek Indonesia.

5. Berdasarkan hasil uji parsial dengan uji F, bahwa Current Rasio, Debt Equity Ratio, Total Asset Turnover dan Net Profit Margin secara bersama-sama tidak berpengaruh terhadap pertumbuhan laba pada perusahaan ritel yang terdapat di Bursa Efek Indonesia.

6. Nilai koefisien determinasi dapat diartikan variabel Current Rasio, Debt Equity Ratio, Total Asset Turnover dan Net Profit Margin secara bersama-sama mampu mempengaruhi pertumbuhan laba sebesar $14,6 \%$, sisanya sebesar $85,4 \%$ dijelaskan oleh variabel atau faktor lainnya. 


\section{REFERENSI}

Abu Bakar Arif. 2006. Analisis Rasio Keuangan Dalam Memprediksi Pertumbuhan Laba Pada Perusahaan Manufaktur Yang Tedaftar di BEJ. Jurnal Informasi, Perpajakan, Akuntansi dan Keuangan Publik Vol 1 (1) : Hal 15-27.

Ageng Setiaji, Hestin Sri Widiawati dan Andy Kurniawan. 2017. "Pengaruh Rasio Keuangan Terhadap Pertumbuhan Laba Pada Perusahaan Infrastruktur, Utilitas, Dan Transportasiyang Terdaftar Di BEI Periode 2013 - 2016”. Jurnal Simki-Economic Vol. 01 (8) : Hal 1-22.

Boy Fadly. 2015. Analisis pengaruh rasio keuangan terhadap pertumbuhan laba pada perusahaan manufaktur yang terdaftar di bursa efek indonesia 2010-2012. Jurnal Bina Akuntansi IBBI Vol 23 No. 1 : Hal 1-7.

Dhany Lia Gustina dan Andhi Wijayanto.2015. Analisis rasio keuangan dalam memprediksi perubahan laba "studi kasus perusahaan manufaktur 2010-2013. Management Analysis Journal Vol 4 (2) : Hal 88-96.

Fahmi, Irham. 2013. Analisis Laporan Keuangan. Bandung: Alfabeta

Ghozali, Imam. 2009. Ekonometrika "Teori, Konsep, Dan Aplikasi Dengan Spss 17". Semarang: Universitas Diponegoro.

Harahap, Sofyan Syafri. 2011. Analisis Kritis atas laporan Keuangan. Edisi PertamCetakan ke sepuluh. Jakarta : PT Bumi Aksara

Hery. 2017. Auditing dan Asurans. Jakarta. Grasindo.

Kasmir, 2008, Analisis Laporan Keuangan, Rajawali Pers, Jakarta

Kasmir. 2009. Pengantar Manajemen Keuangan. Jakarta: Kencana

Kasmir, 2014. Analisis Laporan Keuangan, Edisi Pertama, Cetakan Ketujuh. Jakarta: PT. Rajagrafindo Persada.

Mahaputra, I Nyoman Kusuma Adnyana. 2012. Pengaruh Rasio-Rasio Keuangan Terhadap Pertumbuhan Laba Pada Perusahaan Manufaktur Yang Terdaftar Di Bei. Jurnal Ilmiah Akuntansi dan Bisnis Vol 7.(2) : Hal 243-254.

Maria \& Romas. 2016. Pengaruh rasio keuangan terhadap pertumbuhan laba pada perusahaan manufaktur sektor automotif dan allied product yang terdaftar di bursa efek indonesia. Jurnal Riset Akuntansi dan Keuangan Vol 2 (2) : Hal 191-210.

Munte, Mei Hotma Mariati, Sitanggang dan Thioly Theresia. 2015. Effect Of Financial Ratios On The Growth Of Profit In Manufacturing Industry Listed In Indonesia Stock Exchange. Economics Faculty, University of HKBP Nommensen. Munich Personal RePEc Archive.

Prastowo, Dwi, dan Rifka Juliaty. 2003. Analisis Laporan Keuangan. Edisi Revisi, UPP AMP YKPN, Yogyakarta.

Safitri, Yuna. 2019. Analisis pengaruh rasio keuangan (Likuiditas, Solvabilitas, Aktivitas dan Profitabilitas) terhadap pertumbuhan laba pada perusahaan manufaktur yang terdaftar di Bursa Efek Indonesia Periode 2011-2016. Universitas Sumatera Utara.

Suharti dan Dhea Andriana Kalim. 2019. Analisis Pengaruh Current Ratio, Debt To Equity Ratio, Net Profit Margin Dan Total Assets Turnover Terhadap Perubahan Laba Perusahaan Pertambangan Batu Bara Yang Terdaftar Di BEI Tahun 2013-2017. Jurnal Ilmiah Akuntansi Vol 3 (1) : Hal 32-44 .

Yayuk Retnowati, Jeni Susyanti dan Budi Wahono. 2019. Pengaruh Quick Ratio, Debt To Equity Ratio, Total Asset Turn Over Dan Net Profit Margin Terhadap Pertumbuhan Laba (Studi Pada Perusahaan Pertambangan Sub Sektor Batubara Yang Terdaftar Di Bei Tahun 20142017). Jurnal Ilmiah Riset Manajemen Vol 8 No.2 : Hal 56-67.

Yuni Ajisti Herni. 2019. Pengaruh Rasio Keuangan Terhadap Pertumbuhan Laba Pada Perusahaan Asuransi Yang Terdaftar Di Bursa Efek Indonesia. Sekolah Tinggi Ilmu Ekonomi Keuangan, Perbankan Dan Pembangunan Padang. 